\title{
To Trust or Not to Trust?
}

\section{A Study of Trust and Economic Organization in West Africa}

\begin{abstract}
C.F.A. van Wesenbeeck*
Netherlands

*Corresponding Author: C.F.A. van Wesenbeeck, Netherlands

Abstract: Recent research in development economics suggests that increasing interpersonal (generalized) trust has positive effects on economic development, and should hence be of major concern for many developing countries. This paper models society as being organized along different spheres of intimacy, ranging from the family circle, via circles of acquaintances, to society at large. For economic analysis, it is particularly important to study the relative use of anonymous vs non-anonymous commercial interactions, i.e. interactions in society at large vs in circles of acquaintances only. We hypothesize that (1) each circle of intimacy is characterized by a specific trust level, (2) trust and reliance on specific circles vary between population groups with different cultural embedding, (3) generalized and particular trust move jointly, (4) there is no dichotomy in trust of formal and informal institutional structures, (5) where quality of formal institutions changes, generalized trust changes in the same direction. Using a non-parametric estimation procedure, we find strong support for hypotheses 1 and 3-5 and limited support for hypothesis 2, using data for seven West African countries - Benin, Burkina Faso, Ghana, Liberia, Mali, Nigeria and Senegal, for 2008 and 2011/2013.
\end{abstract}

Keywords: Generalized trust; rule of law; intimacy circles; institutional quality; West Africa; survey analysis

JEL Classification: L14, D11, O21, K42

\section{INTRODUCTION}

Trust has been described as a lubricant without which economic transactions are nearly impossible. Since relying on trust therefore seems inescapable, a number of questions arise. How can trust be defined and measured? How does trust affect the functioning of institutions? Can trust be enhanced by conscious policies or is it culturally determined? A large literature has developed around these types of questions, following different methods.

A first distinction is that between generalized trust and particular trust. Generalized trust is trust between strangers in a society, as opposed to particular trust, which is directed towards particular individuals (e.g. family, friends, people with shared ethnic or religious background). Fukuyama (1995) argues that high generalized trust leads to high economic performance, without, however, formal empirical analysis to support this thesis. La Porta et al. (1997), Knack and Keefer (1997) have taken up this empirical challenge. Using data from the General Society Survey (GSS)/World Values Survey (WVS) of the National Opinion Research Center, they confirm the Fukuyama thesis. Modern approaches use experimental methods (notable the investment or trust-game, introduced by Berg et al, 1995), that also confirm Fukuyama's conjecture (Willinger et al, 2003). Yet, questions with respect to measurement of trust remain, as it seems that outcomes of the investment game frequently are correlated with altruism (Cox, 2004; Ashraf et al. 2006; Capra et al., 2008) and risk-seeking (Karlan, 2005; Schechter, 2007).

These observations led Etang et al (2011) and McEvily et al. (2012) to turn to sociological and sociopsycho-sociological literature on trust that emphasizes the importance of the target or object of trust (Blau, 1964; Luhmann, 1979; Lewis and Weigert, 1985; Johnson-George and Swap, 1982; Rempel and Holmes, 1986; Lewicki and Bunker, 1996), and design a trust game that confirms that individuals discriminate based on perceived characteristics of different targets, with a positive relation between 
social proximity and trust between people. This implies a shift away from generalized to particular trust, a concept closely associated with social networks and personal interactions, not in the least in economic spheres.

"We don't believe in contracts - We believe in relationships". This quote of a Ghanaian enterprise's representative at a conference on economic transformation in Sub-Saharan Africa in 2011 is probably quite an adequate characterization of the majority of economic interactions in Africa. While social proximity, through its impact on trust, shapes the nature and structure of economic interactions in general, it seems to be of particular relevance in Sub-Saharan Africa (see e.g.Fafchamps, 1996 and Lyon, 2000, 2006 on Ghana;Berrou and Combarnous, 2009 on Burkina Faso; Lyons and Snoxell, 2005 andHoogebrugge, 2012 on Kenya; Dickerson, 2007 on Cameroon; Molony, 2007 on Tanzania).

A principal question in developing economics is how to accomplish the transition from a "trustbased" informal economy, which suffers from inefficiencies dueto restrictions of interactions within sub-strata of the economy and necessary investments to maintain social networks (Lyon, 2000; Fafchamps, 2001), to more "institution-based" formalized exchange, with anonymous interactions that are supported by appropriate contract enforcement mechanisms. As is shown in e.g. Rothstein and Uslaner (2005), and Uslaner (2007), such a shift runs parallel to a shift from particular to generalized trust, although it remains a largely open question whether well-functioning institutions induce generalized trust or vice-versa.

This paper aims to find empirical evidence to support or refute basic hypotheses on how to establish a shift from informal to formal institutions, filling a research gap in the literature that is largely theoretical in nature or focuses on the impact of failing formal institutions.

The present study constitutes an empirical check of basic hypotheses, discussed in section 2 of this paper, based on a pooled dataset for West African countries for which data are available (Benin, Burkina Faso, Ghana, Liberia, Mali, Nigeria and Senegal). The choice of region is motivated by the relative connectivity of the region, shared north-south gradient of climate that crosses borders, and access to international markets, while at the other hand, individual countries differ substantially in terms history and culture. This combination of shared and distinguishing factors allows distinguishing long-term trends related to climate and landscape from shorter term impact of colonial rule and policies after independence. In our analytical approach we stay in an observational setting, and estimate the associative relationships between variables by use of conditional densities. Hence, we do not aim at strongly identifying causal relationships in the sense of a treatment effect, because of the complexity of the system we consider, where "trust" as the outcome cannot be directly linked to one or more separate causes. Here, we clearly divert from contributions such as Nunn and Wantchekon (2011), where a clear shock (slave trade) is considered as an explanatory variable for differences in trust, controlling for absolute distance from the coast to argue in favor of a negative relation between slave trade and trust, but without taking into account cultural responses to differences in landscape and climate (e.g. see e.g. Kradin 2008). However, we do include tests that may point at causal directions.

The structure of the paper is as follows. In section 2, we formulate our basic hypotheses. Section 3 describes the data used in the analysis and provides background on the area of study included in the analysis. Section 4 introduces the statistical methodology used in analyzing the data, which is a GISbased approachthat co-integrates geographical and survey information from different sources. Section 5 presents the results and Section 6 comments on the findings and concludes.

\section{BASIC HYPOTHESIS}

The structure of interactions between individuals is not fully flexible. Unlike in a typical economic model, where agents freely exchange all types of goods, our daily experience tells us that we do not treat all other people equally. The exchange of material and immaterial goods is usually group specific. Hence, while universalistic (i.e. the value of a substance is constant, regardless of who provides it) and concrete (or tangible) material substances are more likely to be exchanged in a shortterm, quid pro quo fashion with people with whom we are less intimate, exchange of many immaterial substances is rather characterized by their socio-emotional value, where benefits are highly particularistic and symbolic, i.e. benefits that address one's social and esteem needs (Cropanzano and Mitchell, 2005). Such substances are exchanged in a more open ended manner. According to Blau 
(1964), this type of exchange tends to engender feelings of personal obligation and gratitude. The "social exchange theory" by Cropanzano and Mitchell (2005) also points out the fact that mixing what they call "social exchange" (i.e. exchange of immaterial substances in small intimacy groups) and "economic exchange" (i.e. exchange of material goods in rather anonymous settings) in a relationshiptransaction matrix creates incompatibilities.

From that it follows that the fundamental norm of reciprocity that is inherent to any kind of interaction is treated differently between intimacy groups. Exchange of immaterial substances in small intimacy circles is subject to much higher lenience towards unspecified (in nature and time) reciprocation. Within a family, it is very uncommon to enforce immediate reciprocity between partners, and even more uncommon to expect immediate reciprocity between parents and children. The family members trust that the others will not take permanent advantage of each other. The unidirectional flow of goods without instantaneous recompense results in the accumulation of "social credit", i.e. a debt or an obligation to return the favors in the future, usually without a specific expectation as to how and when the obligation needs to be fulfilled. The aggregate social credit (or debit) that is accumulated by members of a group hence is an indicator of particularized trust. The rather anonymous exchange of material substances, however, in particular of substances that are crucial for our physical and mental health, is to a much higher degree contingent on immediate reciprocation. For society as a whole, in economic terms, immediate reciprocity implies that there is no possibility for accumulating debt, as both ends of every transaction should be carried out instantaneously. There is little tolerance for delays in payments when it comes to "pure business".

The law and the respective means to enforce the law (i.e. the formal institutions) have an impact on the outer intimacy circle, the larger society. The statutes of the law regulate the way people interact by introducing a set of obligations, including reciprocity obligations. The strength, or severity, of order is the capacity of the formal institutions to supervise individual behavior and to punish non-fulfillment of the obligations. We assert that the domain of formal rules is first and foremost the exchange of material goods. Of course, the law also applies to the smaller intimacy circles by imposing behavioral rules that apply to any relationship (you shall not kill, not steal, etc.). However, for the vast majority of interactions in high intimacy groups, in particular with respect to the exchange of immaterial goods, the law is not relevant. As long as there is a mutual understanding of reciprocal obligations, there is no need for law. We thus represent generalized trustby the relative dominance of material exchange in the outer circles as compared to closer networks (family, kin-based exchange).

Where the law is weak, individuals are not capable to enforce reciprocity in anonymous interactions beyond the use of force. As a result, people withdraw into smaller circles that provide the necessary trust environment where supervision and rule enforcement are feasible (e.g. see Fafchamps, 1996 and Lyon, 2000). Such systems of exchange, which are mainly relying on particularized trust, are understood as an endogenous outcome of the social welfare optimizing process, i.e. the result of rational reactions to the severity of order (or the lack of it) in the general society. The extent of informal, relationship-based interactions is a direct consequence of the individual (and social) demand to ensure that promises are kept. People are observed to pursue two strategies. On the one hand, when rule enforcement mechanisms are weak, people "transfer" material exchange from the anonymous circle to the smaller intimacy circles where particularized trust is high. Nepotism and high entry barriers to specific economic activities are characteristic for such societies. On the other hand, people invest time, energy and resources in building up personal ties with their trade partners. Molony (2007), and Lyons and Snoxell (2005) describe how entrepreneurs in Africa go to great lengths, forging alliances with people who belong to the close intimacy circle of their trade counterparts (family, church, village members) in order to ensure that promises are fulfilled.

With respect to trust, we infer that generalized trust in such socio-economic systems is low by definition, and particularized trust in the smaller intimacy circles decreases due to a larger share of material substances that are now entering the budgets (see e.g. Adams and Plaut, 2003). As a market trader in Nairobi put it: "As soon as you mention cash, trust is thrown out" (Lyons and Snoxell, 2005: 1086). Research articles such as Rubbers (2009) confirm this effect. In rural areas, where a large part of the population belongs to the acquaintances or family groups anyway, and where supervision requires little effort, such effects are arguably not very large. However, in heterogeneous societies such as the urban centers in Sub-Saharan Africa where hundreds of different ethnic groups live together, the effect is a considerable fragmentation of society into Chinatown-like settlements and 
small spheres of economic exchange, as shown for the case of migrants to Accra in Van den Berg (2007)andby Lassen (2007)for the effect of ethnic fractionalization on the size of the informal sector. This has become increasingly problematic as the urbanization in Africa is increasing at a rapid rate, and rural-urban migrants often feel trapped between the obligations they have to their relatives and traditional norms for interaction and their aspirations for the future (e.g. see Roth, $2018^{1}$ )for a case study for Burkina Faso, and Casini's (2005) study on entrepreneurs in Ghana).

Contrariwise, in our conceptual framework, an improvement of the functioning of formal institutions induces a shift of material exchange from the circle of family and acquaintances to the wider society circle. The hypothesis is that this leads to several effects. Within the circle of acquaintances, less material goods will be exchanged, particularized trust increases, as the provision of immaterial goods usually does not require immediate reciprocity. The investments people have to make in terms of favors provided to others and efforts to establish relationships decrease, while at the same time the exchange of material goods in the society circle requires little or no provision of immaterial goods: a clear efficiency gain.

In our analysis, we distinguish three circles of intimacy: the family, groups of acquaintances (people you know), and society at large. Following our framework, we understand each of these circles to be characterized by two dimensions. The first dimension is the type of "goods" that are exchanged within each circle - material and immaterial. The second dimension is the degree to which immediate reciprocity between members of the same circle is enforced. We measure the "strength" of the formal institutions, i.e. the degree of law enforcement, by institutional trust. The rationale for applying trust in institutions as an indicator of the rigidity of formal law is based on the theoretical and empirical observation that people who do not trust an institution will arguably have little incentive to appeal to the institution for protection. To the contrary they will try to be "outside the net" (Guha-Kasnobis et al., 2006; Marien and Hooghe, 2011). For the law to be effective, "it must be meaningful in the context in which it is applied, so citizens have an incentive to use the law and to demand institutions that work to enforce and develop the law" (Ehrlich, 1913). Similar arguments are put forward in the institutional economics literature. For example, Berkowitz et al. (2003) argue that the degree of correspondence of formal institutions with the customary set of rules and norms will have implications "for the perception and trustworthiness of the institutions applying them and thus for the future demand for these institutions".

For an empirical evaluation of our theoretical framework, we derive five hypotheses from the above theoretical background:

(1) Each circle of intimacy is characterized by a specific trust level

(2) Trust and reliance of specific circles vary between population groups with different cultural embedding

(3) Generalized and particular trust move jointly

(4) There is no dichotomy in trust of formal and informal institutions

(5) Where quality of formal institutions changes, generalized trust changes in the same direction

The relevance of the hypotheses in assessing the potential for moving from a society characterized by interpersonal relations to a society of anonymous interactions is as follows: if improving formal institutions leads to an increase in generalized trust (5), then this does not go at the expense of informal institutions (4), neither does it undermine trust in acquaintances and family (3), although the trust levels between the different circles remain different (1) and are also determined by factors other than quality of institutions (2). Broadly speaking, this would imply that modernizing societies does not have to go at the expense of close personal relationships, not does it have to imply undermining traditional rules and norms.

\section{Study Area And Data}

Our geographical focus is on seven- largely neighboring - countries in West-Africa: Benin, Burkina Faso, Ghana, Liberia, Mali, Nigeria and Senegal. The study area is selected to cover a wide range of

\footnotetext{
${ }^{1}$ Edited by De Jong et al to honor Claudia Roth's contributions to increase the understanding of social dynamics in Burkina Faso made during her lifetime
} 
different cultural, historical, economic, and agro-climatic settings. For the climate, although West Africa is characterized by relative homogeneity, there is a clear south-north gradient of moisture. Economically, the study area includes coastal areas integrated with the world market as well as remote districts where contacts are predominantly among the local population itself. Historically, the region has a complex background, with different empires and kingdoms controlling parts in different eras, and with a partly shared, partly different colonial past. All these elements have impacted upon culture; impact that is partly related to country borders, but also to a large extent unrelated, leading to crosscountry differences and diversity (e.g see Thébaud and Batterbury, 2001 for a study that reveals the specificities of pastoralist systems). Finally, a practical reason for a restriction to these seven countries in the region is that data is available for all these countries for 2008 as well as 2011-2013, which allows us to track changes in trust levels and patterns.

The territories of Burkina Faso and Senegal were under French rule from 1895/1896 to independence in 1960, and the same more or less holds for Mali and Benin (being French colonies from 1892 to 1960). Ghana has been an English protectorate from 1874 to 1896, and a colony until independence in 1957, while Nigeria became a protectorate in 1901, with colonization lasting until 1960. Finally, Liberia has a history of not being controlled or colonized by European powers. Instead, it was controlled by freed African-American and ex-Caribbean slaves as a free state.

Trade always has been important in the region, and the trading function of the coastal areas in Ghana has led to the development of urban areas where people with many different cultural backgrounds have settled. In Nigeria, the founding of the Sokoto Caliphate, in 1804, provided a boost to regional trade, as its territory expanded to include an area that stretched from modern-day Burkina Faso to Cameroon and including most of Northern Nigeria and Niger.Trade increased over trans-Saharan routes within the Caliphate and commercial prosperity was based on market integration, internal peace and an extensive export-trade network (Lovejoy, 1978; Toyin, 2009; Baten, 2016). In Mali and Senegal, many ancient trading posts (Ségou, Djenné, Tombouctou, Mopti) declined after the heydays of the Mali Empire in the Middle Ages to provincial towns rather than developing into cities. Dakar became an important port for slave trade in colonial times and also experienced rapid growth in recent times (going from an estimated population of 214 thousand people in 1950 to 3.5 million in 2015, UN population division estimated).Bamako, the capital of Mali also has experienced a recent upsurge in growth (going from a population of around 100 thousand in 1960 to 1.8 million in 2009), with a diverse population that flows into the city from rural areas in Mali, but also from neighboring countries. In Burkina Faso, only the capital Ouagadougou (with approximately 1.1 million inhabitants) may be considered a city area. It developed as an administrative center from the $15^{\text {th }}$ century onwards and has served in colonial times as the capital of the region of Upper Volta, before becoming the capital of the independent Burkina Faso. By and large, it can be concluded that the Southern part of Ghana developed into a true urban area, while in the North, a much more rural organization of society has been maintained, even in areas with high population densities.

Nigeria is by far the most densely populated country in West Africa, with high population concentrations along the coast, as other countries, but also in the North. In the north, cities developed to support Saharan and trans-Saharan trade routes, and frequently attracted a large number of traders and migrants from surrounding areas. In the Southeast, cities were organized to facilitate trade to the coast (Chapin Metz, 1991).Hence, also for Nigeria, we expect that city organization differs going south to north, with more mixed populations and cosmopolitan behavior in the South and more segregated urban centers in the North.

Following the theory on the relations between climate and institutions (e.g. Kradin 2008), we hypothesize that, next to country borders, climatic conditions and farming systems (pastoralists versus sedentary agriculture) may play a key role in explaining the differences between regions, with pastoralists being much more dependent on informal institutions for the governance of the scarce, open-access resources (grassland, water) than sedentary farmers, where "modern" institutions such as property rights are more naturally incorporated and less conflicting with traditional rules. Figurepresents the distribution of major farming systems in the region, which highlights the northsouth gradient, but also shows that farming systems across national boundaries, which makes it 
possible to confront similar traditional institutions formed within farming systems over centuries with possibly differing formal institutions in the different nation-states.

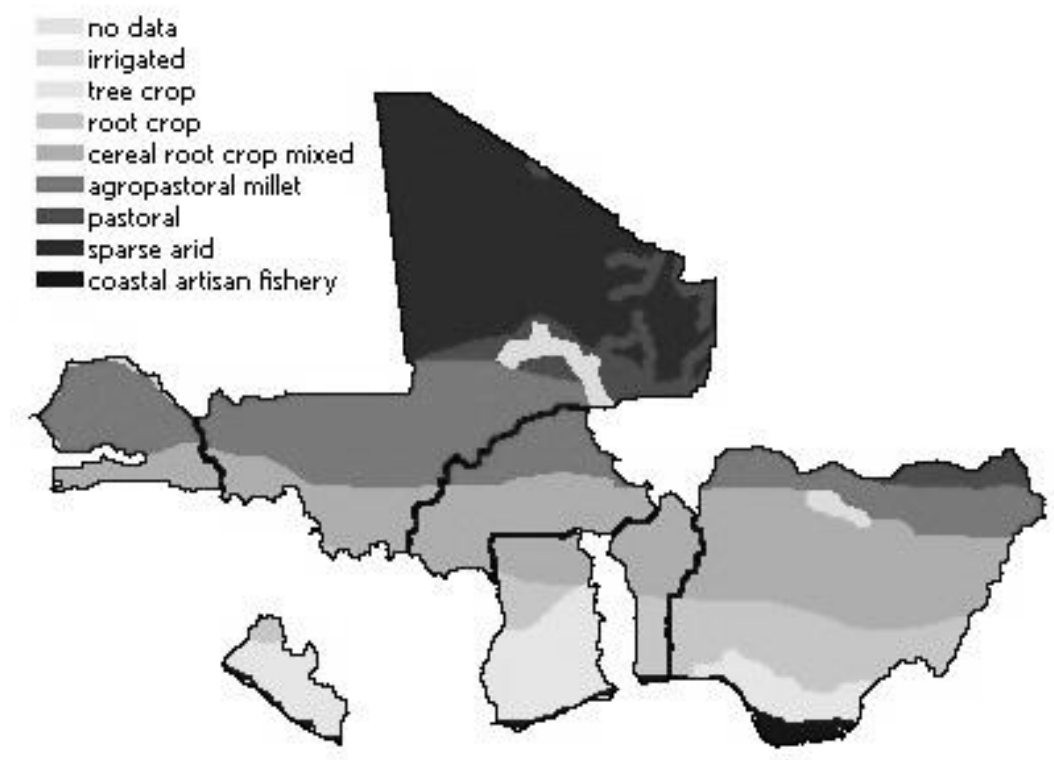

Figure1. Farming systems in the study area.

Source: http://iridl.ldeo.columbia.edu/maproom/.Regional/.Africa/.Farming_Systems

This study employs two types of data. The basic survey data are the Afrobarometer data (Afrobarometer, 2018), round 4, 2008 and round 5, 2011/2013 for all seven countries. Table summarizes the basis statistics on the data. As can be seen, the sampling does not follow the actual division of population in urban and rural areas as reported by the UN population division for all countries in both rounds. Hence, reweighing of observations is needed to obtain results that are representative of the countries.

The Afrobarometer dataset contains over one hundred questions on public opinions, beliefs and attitudes, among others also on trust towards different institutions and towards other people (family, neighbors, strangers). In addition, we use the grid-level data on population densities, and farming systems as a proxy for different ways of organizing society. Although the Afrobarometer dataset is not georeferenced, it includes an indicator of the district (round 4) or province (round 5) in which observations have been collected, and hence we are able to project the survey results on the map and present spatially specific results of our analysis.

Table1. Summary statistics on the Afrobarometer data

\begin{tabular}{|c|c|c|c|c|c|c|c|}
\hline & Benin & Ghana & Liberia & Mali & Nigeria & Senegal & Burkina Faso \\
\hline \multicolumn{8}{|l|}{ Round 4} \\
\hline \# observations & 1192 & 992 & 968 & 1080 & 2001 & 1152 & 1176 \\
\hline$\%$ urban & 0.54 & 0.69 & 0.41 & 0.46 & 0.32 & 0.20 & 0.41 \\
\hline$\%$ urban population & 0.42 & 0.49 & 0.47 & 0.34 & 0.42 & 0.43 & 0.24 \\
\hline Geo-reference & \multicolumn{7}{|c|}{ district } \\
\hline \multicolumn{8}{|l|}{ Round 5} \\
\hline \# observations & 984 & 2168 & 1199 & 1200 & 2400 & 856 & 1200 \\
\hline$\%$ urban & 0.37 & 0.49 & 0.48 & 0.26 & 0.44 & 0.29 & 0.26 \\
\hline$\%$ urban population & 0.44 & 0.51 & 0.48 & 0.37 & 0.44 & 0.44 & 0.25 \\
\hline Geo-reference & \multicolumn{7}{|c|}{ province } \\
\hline
\end{tabular}

Source: Afrobarometer surveys, UN population division

The Afrobarometer survey is designed to measure the social, political, and economic atmosphere in the countries surveyed, with the aim to gain insights in the (change in) attitudes of people regarding democracy, and the functioning of formal and informal institutions. Hence, it is clear that our study uses the Afrobarometer data outside the original scope of the survey. Specifically, we use the three 
related questions: "how much do you trust your relatives?", "how much do you trust other people you know?" and "how much do you trust other people living in the same country?" as indicating the levels of trust in the different intimacy circles and we assume that it represents the degree to which favors done to others must be immediately reciprocated. It may be that respondents answered the questions with specific situations in mind, for example, not being cheated by family or being able to count upon your friend in specific circumstances but maybe not in others. Yet, in the Afrobarometer survey, the three questions are taken to provide insight into the social capital of the respondent, i.e. into the different social networks the individual may have access to. Hence, we are confident that our interpretation of these three questions is in line with the intention of the survey. The appendix lists the questions used and the interpretation given to the questions in our study. Since the Afrobarometer data are specifically gathered to provide insights in the attitudes of people with respect to formal and informal governance processes, we claim that for these questions, we are entirely within the scope of the survey.

\section{EMPIRICAl ANALYSIS: METHOdOLOGiCAl BACKGROUND}

Although it is possible to derive a number of covariates of trust, based on theoretical and empirical research in the fields of social psychology, sociology and economics, it would be presumptuous to assume a specific functional relationship between the exogenous and endogenous variables. In addition, data on most of the characteristics that are of interest for the study are usually collected as the form of pre-coded qualitative questions; hence variables are almost without exception categorical. And last but not least, the issue of trust in the local authorities is naturally spatially diverse due to differences in local policies, the informal structure of society, and urban-rural differences. As such, classical statistical methods such as conventional parametric estimation would not be suitable in this context. Pair-wise cross-tabulation or correlation analysis give little justification for statistical inference as well, because they limit the attention to marginal probabilities, and thus cannot account for the noise introduced by unobserved covariates. In this respect, the polling methodology (e.g. see Wesenbeeck et al, 2016, and Keyzer, M.A. and Pande, S., 2010) is better suited to provide answers to our research questions.

Since we abstain from making any assumption on the specification of the function, we estimate the relationship non-parametrically through conditional probabilities $P(j \mid y)$, where $j$ denotes the realized combinations of all explanatory variables jointly. This gives us sufficient flexibility in terms of statistical inference. On the one hand, the conditional frequencies can be used as a purely descriptive device, with the purpose of achieving a multidimensional profiling of the population, conditional on $y$. On the other hand, the estimation constitutes a regression exercise in its own right that looks for the best explanation of variation in the dependent variable by the set of categorical explanatory variables.

Formally, the statistical analysis is done by

(1) creating a set $J$ of classes $j$ using combinatorics and lexicographic ordering (i.e. $J$ is constructed by crossing a number of underlying variables $x$, where crossing amounts to defining all possible combinations of categories from the set of $x$ ),

(2) calculating the weighted mass for every class $j$, conditional on $y: \pi_{j}(y)=\sum_{i} w_{i} \pi_{i j}(y)$

(3) selecting the $\bar{N}(y)$ in terms of payoff $\pi_{j}(y)$ most rewarding classes according to:

$$
\begin{aligned}
& \delta_{j}(y)=\max _{\delta_{j} \in\{0,1\}}\left\{\sum_{j} \pi_{j}(y) \delta_{j} \mid \sum_{j} \delta_{j}=\bar{N}(y)\right\}, \quad \text { which } \quad \text { gives } \quad \text { the } \quad \text { set } \\
& \bar{J}(y)=\left\{j(y) \mid \delta_{j}(y)=\bar{N}(y)\right\} \text { of winning classes. }
\end{aligned}
$$

Since this procedure optimizes over a discrete set, it can for all $y$ find the globally optimal profile $\delta_{j}(y), j \in \bar{J}(y)$, irrespective of the shape of the underlying mass distribution, i.e. of nonconvexities.

In a subsequent step, the estimated probabilities can be used to produce post-estimation statistics. For example, from the conditional (joint) frequency distributions we are able to derive the marginal 
distribution of every variable $x$ for the subset $\bar{J}(y)$ of winning classes, by calculating the mass of $k(x)$ (the categories of a variable):

$\bar{\pi}_{k(x)}(y)=\sum_{j \in \bar{J}(y) \cap J_{k(x)}(y)} \pi_{j}(y), J_{k(x)}(y)=\{j(y) \mid k(x)\}, \bar{J}(y)=\left\{j(y) \mid \delta_{j}(y)=\bar{N}(y)\right\}$,

and

$\bar{P}(k(x) \mid y)=\frac{\bar{\pi}_{k(x)}(y)}{\sum_{j \in \bar{J}(y)} \pi_{j}(y)}$.

The difference $\Delta \bar{P}(k(x) \mid y)=\bar{P}(k(x) \mid y=1)-\bar{P}(k(x) \mid y=0)$ thus represents the difference in item preference between the high-trust and low-trust groups. A high difference indicates that there is a strong association between the item $x$ and the choice of a category of $y$. If the population in $y=1$ is less (or more) supportive of $k(x)$, then item $x$ is arguably an important characteristic that differentiates individuals who choose $y=1$ from those that opt for $y=0$.

\section{Results}

This section considers the five main hypotheses of the paper. Here, we note that the hypotheses on impact of cultural embedding and relation between trust in formal and informal institutions can only be addressed with data from the first round as information in round 5 is lacking (either on location or in terms of questions included). Hence, for hypotheses (1), (4) and (5), both rounds of data are used and trends discussed, and for (2) and (3) only round 4 data are relied upon.

\subsection{Each Circle of Intimacy is Characterized by a Specific Trust Level}

The Afrobarometer survey has three questions that specifically address the levels of trust in the three circles of intimacy:

(1) How much do you trust each of the following types of people: Your relatives?

(2) How much do you trust each of the following types of people: Other people you know?

(3) How much do you trust each of the following types of people: Other people in your country?

For each of these questions, respondents can select one of the following answers, recoded as specified here: 1="Not at all", 2 ="Just a little", 3= "I trust them somewhat", 4= "I trust them a lot",9999="Don't know, refused to answer, missing data.

As Figure shows, there are differences between trust levels in the different circles for round 4 , with highest levels for family, followed by acquaintances and strangers. The graph shows both the distribution of observations as well as the average trust score. Differences between urban and rural observations within each circle as well as differences between circles are all significant at the $1 \%$ level. The same pattern arises for the round 5 data (Figure 5), again with all differences being significant at the $1 \%$ level. 


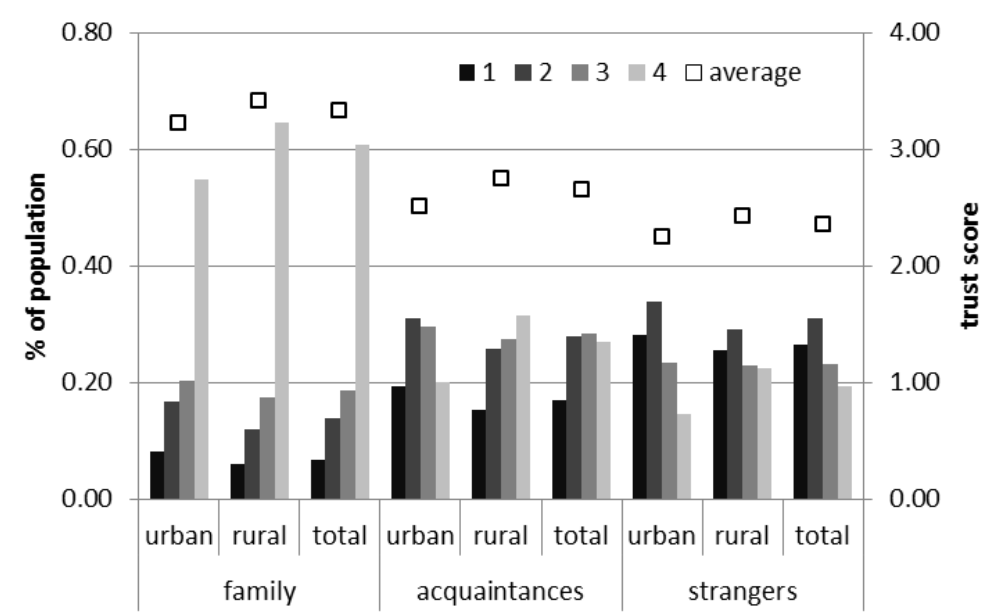

Figure2. Trust levels for different circles, distribution and average, round 4

Note: Trust is measured on a scale from 1 (don't trust at all) to 4 (trust a lot)

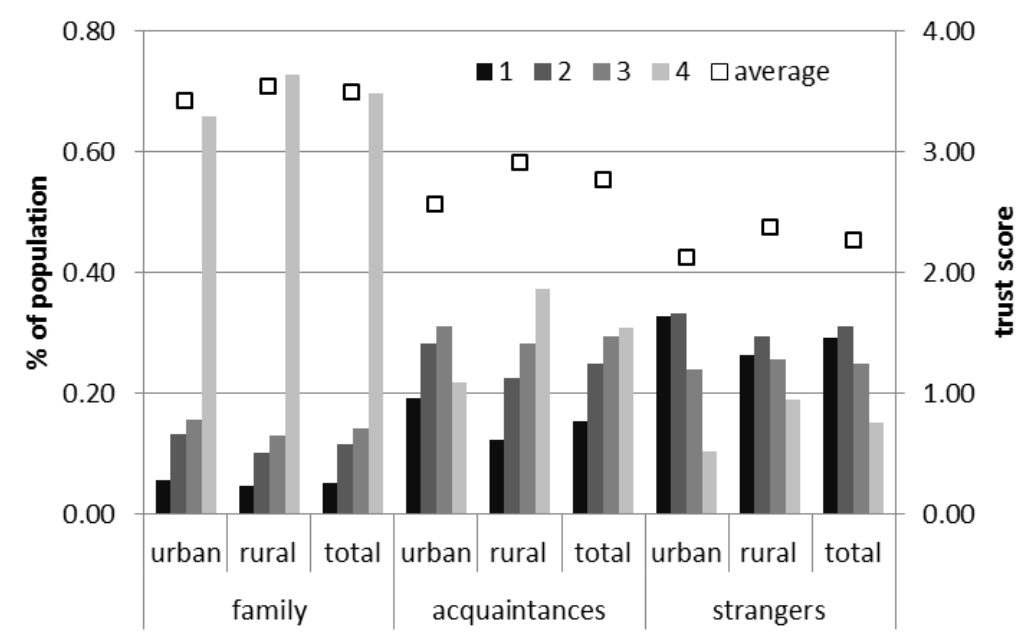

Figure3. Trust levels for different circles, distribution and average, round 5

Note: Trust is measured on a scale from 1 (don't trust at all) to 4 (trust a lot)

\subsection{Trust within specific circles varies between different cultural environments}

There is some evidence that trust levels differ between different cultural environments (e.g. see Buchan and Croson, 2004; Buchan et al., 2006). Hence, as a first proxy, we take the countries as cultural entities. Weighted average trust scores by country and rural/urban regions have been computed for each of the three circles, for both rounds (Figure, Figure).

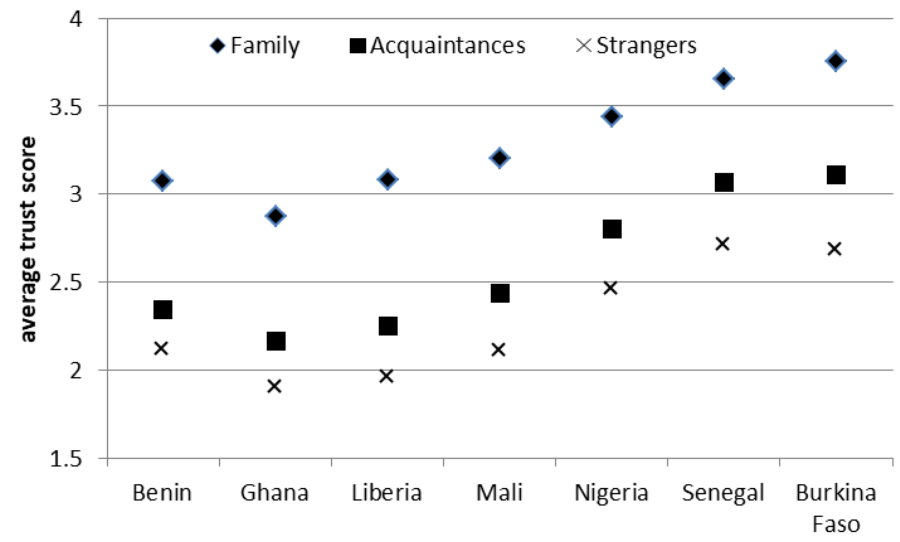

Figure4. Average trust scores by country, round 4

Note: Trust is measured on a scale from 1 (don't trust at all) to 4 (trust a lot) 


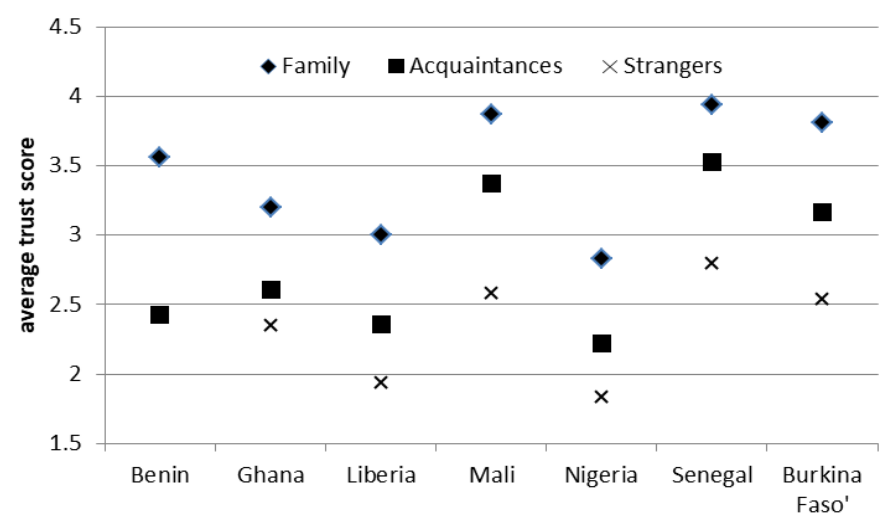

Figure5. Average trust scores by country, round 5

Note: Trust is measured on a scale from 1 (don't trust at all) to 4 (trust a lot)

For round 4, differences are statistically significant for all countries except for Benin-Liberia, BeninMali, Senegal-Burkina Faso and Liberia-Mali (for family trust). For round 5, there is even more diversity in country trust scores, suggesting that as time progresses, country culture becomes more important and distinct. However, this does not rule out that other, older cultural roots play a role as well, and to test this, as a second approach, farming systems are used as a proxy for cultural environments as it is well known that societies of pastoralists are characterized by very different social ties and institutions than sedentary societies (e.g. Catley et al., 2013).

Given that the geographic division of farming systems has remained roughly unchanged over large periods of time, cultural differences associated with these different systems should be pronounced and cross-boundary. Since the geo-referencing of the data allow a crossing with farming systems only for round 4 data, we base our analysis on the data for 2008 only. The analysis, where weighted average trust scores by farming system are compared confirm that trust is decreasing when moving from the inner intimacy circle of family to the outer circle of anonymity, but also suggests that the intimacytrust relation is different along the cultural dimension(Figure), though the variation over farming systems varies.

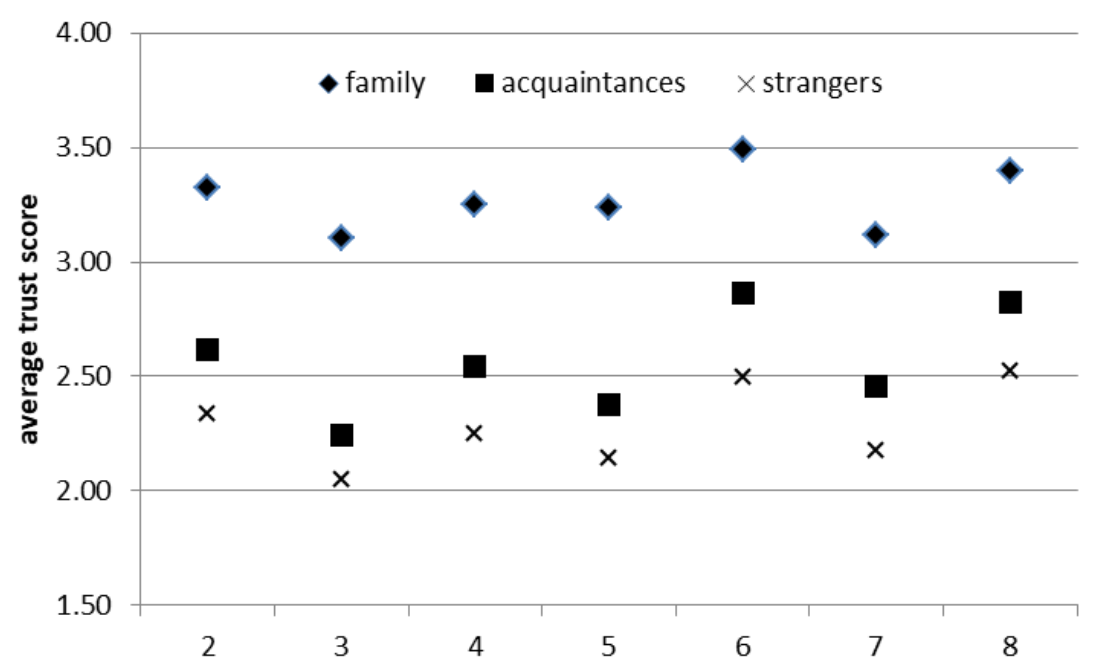

Figure6. Average trust score by farming system

Note: Trust is measured on a scale from 1 (don't trust at all) to 4 (trust a lot), 2=agro-pastoral millet/sorghum, $3=$ pastoral, $4=$ arid, $5=$ coastal artisan fishing, $6=$ tree crop, $7=$ root crop, $8=$ cereal-root crop

A test on the significance of the differences between farming systems reveals that there seems to be less difference between farming systems than between countries, which reinforces the conclusion that as time passes, the national borders - and hence national culture and policies - become more important than more ancient cultural ties. For coastal fisheries, the relatively small number of observations may disturb the outcomes, but for root crop and cereal-root crop systems, there seems to 
be a robust conclusion on similarity between these and other systems, across all three circles of intimacy

Although the univariate analysis suggests that culture matters, an interesting question is whether this is more important that characteristics of individuals. To select respondent-specific variables for inclusion, three groups of potentially important factors are identified. Area characteristics reflect the access to basic services and hence the overall social-economic status of the area (availability of electricity grid, piped water, sewage system). Poverty indicators reflect the relation between trust and individual wealth (e.g. Zak and Knack, 2001) and include measurements of how often household have gone without food, water, medical care and cooking fuel. Sources of news(radio, tv, newspaper) are included since there is evidence that the type of media used to obtain news matters for trust, as different media present news in different ways and speed (e.g. see Han et al., 2019). Exposure to the outside world(use of cell phone, computer, internet, travelling more than $10 \mathrm{~km}$ ) captures the extent to which people are aware of "others" outside their own comfort zone (note that Putnam, 1995a,b, 1996 argues that there will be negative impact on trust, particularly of watching television, while e.g. Uslaner, 1998 has found empirical evidence to the contrary), while the personal characteristics reflect age, general education (there is no variable in the Afrobarometer measuring educational attainment; a proxy for this is the number of languages spoken) and integration in religious of community groups. (Zak and Knack, 2001)

Univariate tests reveal that there are no significant differences in mean trust scores for different area characteristics. For the poverty indicators, differences are significant when classes are joined into "never/once, twice" and "several, many times, always", while the same holds for sources of news, use of cell phone, computer, and the internet (never/less than once a month vs few times a month and more). Travelling does not seem to have a significant impact on trust levels. Differences between age classes all seem to be significant; for number of languages, the significant difference seems to be between 1 and more than 1 . Finally, membership of religious or community group significantly impacts on trust levels, in line with the findings of e.g. Welch et al. (2007).These different indicators are combined into profiles, using the methodology introduced in section 4.These variables are included jointly with a country and farm system indicator. Polling with 5 variables at a time is then used to analyze the relative importance of cultural vs personal characteristics.

For trust in family members, the country variable does not figure in the top-5 profiles ranked by edge, nor in the top- 5 ranked by coverage, while farming systems variables do appear in the top- 5 of profiles ranked by edge, but only in characterizing households with higher trust levels (somewhat/a lot of trust). For trust in acquaintances, the same conclusion for the country variable follows from the analysis, but farming systems are now included in the top-5 of profiles for all trust levels. Finally, for general trust (trust in strangers), the farm system variable is again represented in the top-5 profiles, with the country variable again being totally absent. On the whole, though, it seems that both farming systems and county variables are not dominant factors associated with different levels of trust. Hence, for round 4 , it seems that the hypothesis that trust varies with cultural environments cannot be confirmed when other variables are included. For round 5, only a correlation with the country variable can be checked, using the same set of other variables as used for round 4. Here, the results point at a limited impact of culture (country) only, where the correlation seems to be largest for trust in relatives, and smallest for trust in acquaintances. Hence, in general, the impact of culture on trust seems to be less than the impact of individual characteristics.

\subsection{Generalized and Particular Trust Move Jointly}

The hypothesis that generalized trust and particular trust move together implies that there is no tradeoff between trust in your family members and acquaintances on the one hand and trust in strangers on the other hand. In particular, this implies that high trust in those close to you would not be mirrored by low trust in strangers. It may seem reasonable to assume that the relation between generalized trust and trust in acquaintances will be more closely related than generalized trust and trust in family members, as relying on acquaintances for economic interaction may be the alternative when trust in strangers is low. However, as Table and Table suggest, there is positive correlation (diagonal dominance both for generalized trust on trust in acquaintances and for the reverse). We note here that the strength of the relation between particular and generalized trust varies over the countries - 
corroborating the findings by e.g. Glanville and Shi (2019) for a wide range of countries, but that for all countries, the positive correlation holds.

What we may conclude from the above analysis is that there seems to be a common underlying cause for high or low trust among people; trust in acquaintances and in strangers moves together rather than opposite.

Table3. Likelihood of generalized trust conditional on trust in acquaintances

\begin{tabular}{|c|c|c|c|c|c|}
\hline & Generalized trust & & & & \\
\hline \multirow{11}{*}{ 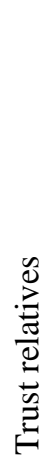 } & & not at all & just a little & somewhat & a lot \\
\hline & & \multicolumn{4}{|l|}{ Round 4} \\
\hline & not at all & 89.9 & 6.1 & 1.8 & 2.1 \\
\hline & just a little & 23.7 & 69.0 & 5.6 & 1.7 \\
\hline & Somewhat & 9.5 & 29.2 & 58.5 & 2.8 \\
\hline & a lot & 8.7 & 10.6 & 19.2 & 61.5 \\
\hline & & \multicolumn{4}{|l|}{ Round 5} \\
\hline & not at all & 88.8 & 7.3 & 2.7 & 1.1 \\
\hline & just a little & 28.5 & 63.7 & 6.9 & 1.0 \\
\hline & Somewhat & 14.4 & 32.1 & 51.1 & 2.5 \\
\hline & a lot & 13.8 & 15.1 & 25.1 & 45.9 \\
\hline
\end{tabular}

Table4. Likelihood of trust in acquaintances conditional on generalized trust

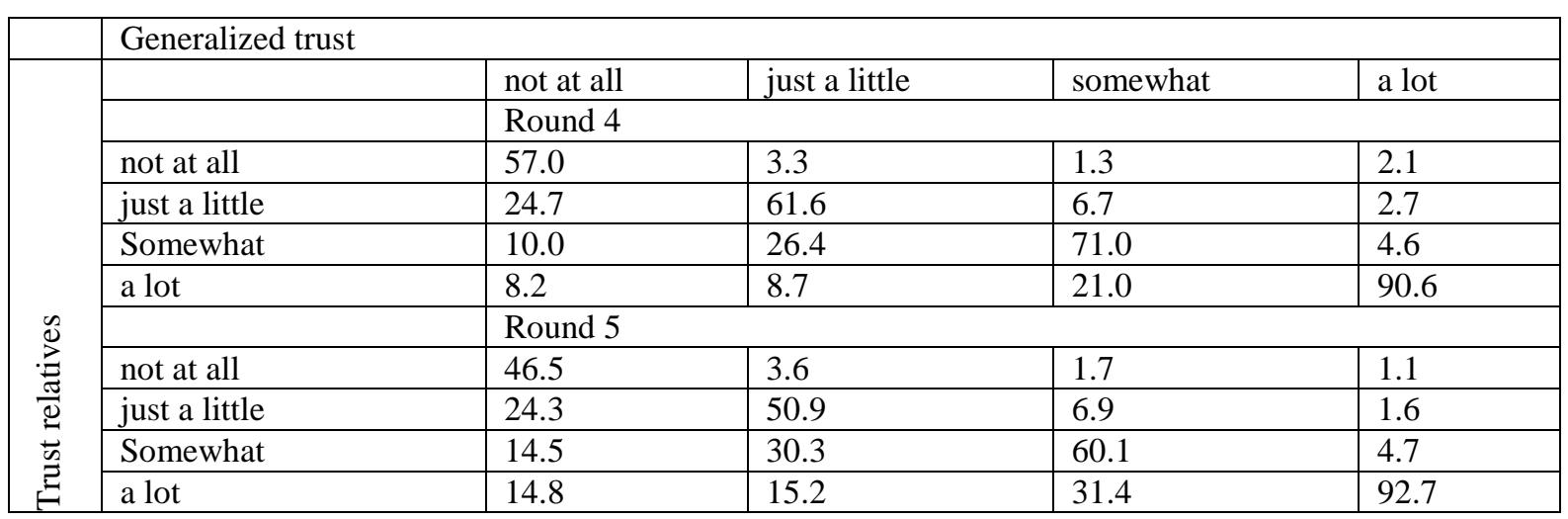

\subsection{There is no Dichotomy in Trust in Formal and Informal Institutions}

This section tests the relation between trust in formal and informal institutions and generalized trust. Unfortunately, only in round 4 of the Afrobarometer survey, questions are included on trust in formal as well as informal institutions. Hence, we have to rely on round 4 data only. To test the hypothesis, we use comparisons of trust, using the indicator "trust in traditional leaders" for trust in informal institutions, and "trust in parliament", "trust in national electoral commission", "trust in local government council", "trust in police" and "trust in courts of law" to represent trust in formal institutions. Using polling, we find that the most likely combination of outcomes for the trust in formal institutions is as in Table. It shows that the most likely combinations of trust in formal and informal institutions all are aligned: for all outcomes for trust in informal leaders, the outcomes for trust in formal institutions are the same, with a very high coverage (share of outcomes for trust covered by winning profile) and also very high edge (likelihood of winning profile over second best). Hence, we conclude that there is no dichotomy when the point of view of trust in informal leaders is taken. To complement this analysis, we also analyzed the most likely outcomes for each of the formal institutions. For each of these, the most likely profile is also the one that has the same trust levels for all variables, again with very high values for the edge and with coverage rates ranging between 14 and $39 \%$.

Based on this analysis, we conclude that there is firm evidence that there is no dichotomy in trust between informal and formal institutions.

Table5. Winning combinations of outcomes for trust in formal and informal institutions

\begin{tabular}{|l|l|l|l|l|}
\hline trust informal leaders & not at all & just a little & somewhat & a lot \\
\hline Trust parliament & not at all & just a little & somewhat & a lot \\
\hline
\end{tabular}


To Trust or Not to Trust? A Study of Trust and Economic Organization in West Africa

\begin{tabular}{|l|l|l|l|l|}
\hline Trust NEC & not at all & just a little & somewhat & a lot \\
\hline Trust local government council & not at all & just a little & somewhat & a lot \\
\hline Trust police & not at all & just a little & somewhat & a lot \\
\hline Trust courts of law & not at all & just a little & somewhat & a lot \\
\hline coverage & 0.33 & 0.18 & 0.14 & 0.21 \\
\hline edge & 13.27 & 5.42 & 5.94 & 10.04 \\
\hline
\end{tabular}

\subsection{Quality Changes of Formal Institutions Cause Related Changes in Generalized Trust}

The final hypothesis to be tested is whether institutional quality influences generalized trust, i.e. whether policies to improve the quality of institutions (in this paper specifically reducing corruption) are effective in increasing generalized trust. Again, only data in round 4 of the survey is available for testing, where generalized trust is paired with corruption of police officers; tax officials and judges. As in the previous section, we apply polling to look for the most likely outcome for trust given particular levels for corruption of officials. As Table shows, when all officials are considered to be corrupt, the most likely outcome for trust is to trust no one at all, with that outcome being more than twice as likely as the second most likely one. When most or some are considered to be corrupt, there is just a little trust in strangers (with edges being not very high), and when none of the government officials is considered to be corrupt, general trust is very high, with an edge that still gives sufficient confidence in the dominancy of the winning profile (40\% more likely than second best). For the cases where most or some officials are considered to be corrupt, the second-best outcomes for trust are "somewhat" and "not at all", respectively, confirming the negative relation between corruption and general trust in society. To test whether the causality runs from corruption to trust instead of viceversa, we also analyzed the dominant profiles of perceived corruption for given trust levels. Here, we find that for all trust levels, the dominant profile is that some officials are considered to be corrupt. Hence, there is no evidence that different levels of trust lead to different reported levels of corruption and we conclude that indeed, combating corruption leads to increased general trust in West African societies.

Table6. Winning combinations of outcomes for trust given corruption in formal institutions

\begin{tabular}{|l|l|l|l|l|}
\hline corruption police & All & Most & Some & None \\
\hline corruption tax officials & All & Most & Some & None \\
\hline corruption courts & All & Most & Some & None \\
\hline General trust & not at all & just a little & Just a little & a lot \\
\hline Coverage & 0.39 & 0.34 & 0.34 & 0.36 \\
\hline Edge & 2.12 & 1.11 & 1.34 & 1.41 \\
\hline
\end{tabular}

\section{CONCluding Remarks}

In this paper we sketch a theoretical framework for the analysis of economic interactions by extending the conventional economic concept to include material and immaterial exchange conditional on the circle of intimacy. In particular we focus on the relationship between institutional and generalized trust.

Based on our conceptual framework we derive five hypotheses and using a spatially explicit approach for our multivariate non-parametric analysis we are able to identify structural patterns of interdependencies between different types of trust, and relations with functioning of institutions, accounting for the heterogeneity of the socio-cultural settings below country level.

Our analysis reveals some interesting, and partly surprising, findings. First, of all, the results confirm that there is a robust distinction between trust levels in the three levels of intimacy, with trust levels being consistently lower for generalized trust than for particularized trust, and lower for acquaintances than for family. However, we do find that there are large differences within the study region with respect to levels of trust, as well as differences in trust between circles. These differences can to some extent be related to country-specific differences in cultural heritage, but correlate more with individual characteristics.

The estimation results from our models show that there is a recognizable link between trust in formal institutions and general trust in society, confirming Baliamoune-Lutz' (2011: p.344) conjecture that "social capital and political institutions in Africa complement each other". Our associative analysis suggests that political trust is not just a positive side-effect of historically and culturally determined generalized trust. This finding lends some support to the theoretical hypothesis that institutional and interpersonal trust levels are the outcome of a simultaneous dynamic process. The knowledge that 
institutions are there, and that they can be trusted, goes hand in hand with an atmosphere of trust for interpersonal relationships. This finding is of particular relevance with regard to the issue of "good governance" that has dominated political discourse in the past decades. It is unlikely that local governments' actions to gain public support for their policies, development projects, regulations and enforcement of rules, will have clear-cut and predictable consequences. Due to the complexity and dynamics of the socio-economic systems, policy interventions might have quite undesirable outcomes, as for example described by Meagher (2006). Nonetheless, our results confirm the intuition that if institutions (formal and informal) "behave well", they may foster generalized trust, without having a negative impact on personal relations and on the functioning of informal cultural norms and rules.

This is corroborated by the finding that we do not find a dichotomy between trust in formal and informal institutions. We hence infer that policy suggestions should put less emphasis on the formalinformal institutional duality, but rather on improving the performance, visibility and accountability of formal institutions. This can possibly be achieved through incentive schemes for government officials, which make them having a stake in the functioning of the socio-economic system for which they are responsible, and by explicitly including informal mechanisms and regulations in formal laws if they are functioning well.

Further research will have to dig deeper in the dynamics of trust and its relation with modernization and urbanization of societies; our results may provide a first indication of potential policy priorities in this respect.

\section{REFERENCES}

[1] Adams, G. and Plaut, V.C., 2003. The cultural grounding of personal relationship: Friendship in North American and West African worlds. Personal Relationships 10, 333-347.

[2] Afrobarometer, 2017. http://www.afrobarometer.org/

[3] Ashraf, N., I. Bohnet and N. Piankov, 2006. Decomposing trust and trustworthiness. Experimental Economics 9(3): 193-208.

[4] Baliamoune-Lutz, M. 2011. Trust-based social capital, institutions, and development. The Journal of Socio-Economics 40, 335-346.

[5] Baten, J., 2016. A History of the Global Economy. From 1500 to the Present. Cambridge University Press.

[6] Berg, J., . Dickhaut and K. McCabe, 1995. Trust, Reciprocity, and Social History. Games and Economic Behavior 10, 122-142.

[7] Berrou, J.-P. and F. Combarnous, 2009. Measuring entrepreneurs' social networks and their economic impact in the African informal economy. IARIW-SAIM Conference "Measuring the Informal Economy in Developing Countries", 24/26 September, Kathmandu, Nepal.

[8] Blau, P., 1964. Exchange and Power in Social Life. New York: John Wiley and Sons, Inc.

[9] Capra, C.M., K. Lanier and S. Meer, 2008. Attitudinal and behavioral measures of trust: a new comparison. Department of Economics, Emory University. Available at URL: https://www.gate.cnrs.fr/IMG/pdf/Capra.pdf

[10] Casini, S., 2005. Negotiating Personal Success and Social Responsibility: Assessing the Developmental Impact of Ghanaian Migrants' Business Enterprises in Ghana. MA thesis at the International School for Humanities and Social Sciences, University of Amsterdam.

[11] Catley, A., J. Lind and I. Scoones (eds.) (2013) Pastoralism and development in Africa, dynamic change at the margins, London and New York: Routledge.

[12] Chapin Metz, H., 1991. ( ed). Nigeria: A Country Study. Washington: GPO for the Library of Congress, 1991.

[13] Cox, J., 2004. How to identify trust and reciprocity. Games and Economic Behavior 46: 260-281.

[14] Cropanzano, R. and Mitchell, M.S., 2005. Social Exchange Theory: An Interdisciplinary Review. Journal of Management 31(6), 874-900.

[15] Dickerson, C.M., 2007. The Cameroonian Experience under OHADA: Business Organizations in a Developing Economy. Business and Society Review 112(2), 191-213.

[16] Ehrlich, E., [1913],2001. Fundamental Principles of the Sociology of Law.New Brunswick: Transaction Publishers.

[17] Etang, A., D. Fielding and S. Knowles, 2011. Does trust extend beyond the village? Experimental trust and social distance in Cameroon. Experimental Economics 14(1): 15-35. 
[18] Fafchamps, M., 1996. The enforcement of commercial contracts in Ghana. World Development24 (3), 427-448.

[19] Fafchamps, M., 2001. Networks, Communities and Markets in Sub-Saharan Africa: Implications for Firm Growth and Investment. Journal of African Economies 10 (Suppl.1), 109-142.

[20] Fukuyama, F., 1995. Social capital and the global economy: a redrawn map of the world. Foreign Affairs, 74(5): 89-103.

[21] Glanville, J.L., and Shi, Q., 2019. The extension of particular trust to generalized and out-group trust: the constraining role of collectivism. Social Forces, soz114, https://doi.org/10.1093/sf/soz114

[22] Goldschmidt, W., 1971 Independence as an element in pastoral social systems. Anthropological Quarterly, 44(3) : 132.

[23] Guha- Khasnobis, B., Kanbur, R. and Ostrom, E., (Eds.), 2006. Linking the Formal and Informal Economy: Concepts and Policies. Oxford: Oxford University Press.

[24] Han, L., R. Sun, F. Gao, Y. Zhou and M. Jou (2019) the effect of negative energy news on social trust and helping behavior. Computers in Human Behavior, 92: 128-138.

[25] Hoogebrugge, A., 2012. Trust in Mitumba: Trade relationships in the Kenyan second-hand clothing market. Master thesis in Cultural Anthropology, Leiden University.

[26] Johnson-George, C., and W.C. Swap, 1982. Measurement of specific interpersonal trust: construction and validation of a scale to assess trust in a specific other. Journal of Personality and Social Psychology, 43(6): 1306-1317.

[27] Karlan, D., 2005. Using experimental economics to measure social capital and predict financial decisions. American Economic Review 95(5): 1688-1699.

[28] Keyzer, M.A. and Pande, S., 2010. Classification by crossing and polling for integrated processing of maps and surveys - An addendum to GRC software, Version 2. SOW-VU Working Paper WP-10-01.

[29] Knack, S. and P. Keefer, 1997. Does social capital have an economic payoff? A cross-country investigation, Quarterly Journal of Economics 112: 1251-1288.

[30] Kradin, N.N. 2008. Early state theory and the evolution of pastoral nomads. Social evolution and history 7(1), 107-130

[31] La Porta, R., F. Lopez-de-Silanes, A. Shleifer and R.W. Vishny, 1997. Trust in large organizations. American Economic Review, Papers and Proceedings 87: 333-338.

[32] Lassen, D.D., 2007. Ethnic divisions, trust, and the size of the informal sector. Journal of Economic Behavior and Organization 63, 423-438.

[33] Lewicki, R.J. and B.B. Bunker, 1996. Developing and maintaining trust in work relationships. In R. Kramer \& T. R. Tyler (Eds.), Trust in organizations: Frontiers of theory and research: 114-139. Thousand Oaks, CA: Sage.

[34] Lewis, J.D. and A. Weigert, 1985. Trust as a social reality. Social Forces, 63: 967-985.

[35] Lovejoy, P., 1978. Plantations in the Economy of the Sokoto Caliphate. The Journal of African History. 19 (3): 341-368.

[36] Luhmann, N. 1979. Trust and power. Chichester, UK: Wiley.

[37] Lyon, F., 2000. Trust, Networks and Norms: The Creation of Social Capital in Agricultural Economies in Ghana. World Development 28(4), 663-681.

[38] Lyon, F., 2006. Managing Co-operation: Trust and Power in Ghanaian Associations. Organization Studies 27(1), 31-52.

[39] Lyons, M. and Snoxell, S., 2005. Creating Urban Social Capital: Some Evidence from Informal Traders in Nairobi. Urban Studies 42(7), 1077-1097.

[40] Marien, S. and Hooghe, M., 2011. Does political trust matter? An empirical investigation into the relation between political trust and support for law compliance. European Journal of Political Research 50, 267-291.

[41] McEvily, B., J.R. Radzevick, and R.A. Weber, 2012. Whom do you distrust and how much does it cost? An experiment on the measurement of trust. Games and Economic Behavior, 74(1): 285-298

[42] Meagher, K., 2006. Social capital, social liabilities, and political capital: Social networks and informal manufacturing in Nigeria. African Affairs 105/421, 553-582.

[43] Molony, T., 2007. 'I Don't Trust the Phone, It Always Lies': Trust and Information and Communication Technologies in Tanzanian Micro- and Small Enterprises. Information Technologies and International Development 3(4), 67-83.

[44] Putnam, R.D. 1995a. Bowling alone: America's declining social capital. Journal of Democracy, 6: 65-78.

[45] Putnam, R.D., 1995b. Tuning in, tuning out: the strange disappearance of social capital in America. Political Science and Politics, 28: 664-683. 
[46] Putnam, R.D., 1996. The strange disappearance of civic America. The American Prospect (Winter), 34-48.

[47] Rempel, J.K. andJ.G. Holmes, 1986. How do I trust thee? Psychology Today, 28-34.

[48] Roth, C. (2018) Urban Dreams: transformations of family life in Burkina Faso. W. de Jong and M. Perlik, eds. Berghahn books.

[49] Rothstein, B. and E.M. Uslaner, 2005. All for all: equality, corruption and social trust. World Politics, 58(1): 41-72.

[50] Rubbers, B., 2009. 'We, the Congolese, we cannot trust each other' - Trust norms and relations among traders in Katanga, Democratic Republic of Congo. The British Journal of Sociology 60(3), 623-642.

[51] Schechter, L., 2007. Traditional trust measurement and the risk confound: An experiment in rural Paraguay. Journal of Economic Behavior and Organization 62: 272-292.

[52] Thébaud, B. and S. Batterbury, 2001. Sahel pastoralists: opportunism, struggle, conflict and negotiation. A case study from eastern Niger. Global environmental change, 11(1): 69-78.

[53] Toyin, F. 2009. Historical Dictionary of Nigeria. Lanham, Md: Scarecrow Press.

[54] UN population division. URL: http://www.un.org/en/development/desa/population/

[55] Uslaner, E.M., 1998. Social capital, television and the "mean world": trust, optimism, and civic participation. Political Psychology, 19(3): Special issue: 441-467.

[56] Uslaner, E.M., 2007. Corruption, inequality and the rule of law: the bulging pocket makes the easy life. New York: Cambridge University Press

[57] Van den Berg, C., 2007. The Kayayei: Survival in the City of Accra. Master of Philosophy Thesis, University of Amsterdam.

[58] Van Wesenbeeck, C.F.A., B.G.J.S. Sonneveld and R.L. Voortman, 2016. Location and characterization of populations vulnerable to climate change: two case studies in Sub-Saharan Africa. Applied Geography 66: $81-91$.

[59] Welch, M.R., Sikkink, D., Loveland, M.T., 2007. The radius of trust: religion, social embeddedness and trust in strangers. Social Forces, 86(1): 23-46.

[60] Willinger, M. Keser, C., Lohmann, C., andUsunier, J.-C., 2003. A comparison of trust and reciprocity between France and Germany: experimental investigation based on the Investment Game. Journal of Economic Psychology, 24(3): 447-466.

[61] Zak, P.J. and S. Knack, 2001. Trust and growth. The Economic Journal, 111(4): 295-321.

Appendix A. Measurement of trust and question phrasing for variables used in the analysis

\begin{tabular}{|c|c|c|}
\hline $\begin{array}{l}\text { Measured } \\
\text { item }\end{array}$ & Question phrasing & $\begin{array}{l}\text { Possible } \\
\text { outcomes }\end{array}$ \\
\hline $\begin{array}{l}\text { Generalized } \\
\text { trust }\end{array}$ & $\begin{array}{l}\text { How much do you trust each of the following types of people: Other [people } \\
\text { living in country] }\end{array}$ & $\begin{array}{l}\text { Not at all, } \\
\text { just a little, } \\
\text { I trust them } \\
\text { somewhat, } \\
\text { I trust them } \\
\text { a lot }\end{array}$ \\
\hline $\begin{array}{l}\text { Trust } \\
\text { relatives }\end{array}$ & $\begin{array}{l}\text { How much do you trust each of the following types of people: Your } \\
\text { relatives? }\end{array}$ & $\begin{array}{l}\text { Not at all, } \\
\text { just a little, } \\
\text { I trust them } \\
\text { somewhat, } \\
\text { I trust them } \\
\text { a lot }\end{array}$ \\
\hline $\begin{array}{l}\text { Trust in } \\
\text { acquaintances }\end{array}$ & $\begin{array}{l}\text { How much do you trust each of the following types of people: Other people } \\
\text { you know? }\end{array}$ & $\begin{array}{l}\text { Not at all, } \\
\text { just a little, } \\
\text { I trust them } \\
\text { somewhat, } \\
\text { I trust them } \\
\text { a lot }\end{array}$ \\
\hline $\begin{array}{l}\text { Area } \\
\text { characteristics }\end{array}$ & $\begin{array}{l}\text { Are the following services present in the primary sampling unit: electricity } \\
\text { grid that most houses could access } \\
\text { Are the following services present in the primary sampling unit: piped water } \\
\text { system that most houses could access } \\
\text { Are the following services present in the primary sampling unit: sewage } \\
\text { system that most houses could access }\end{array}$ & $\begin{array}{l}\text { No, Yes, } \\
\text { Can't } \\
\text { determine }\end{array}$ \\
\hline
\end{tabular}




\begin{tabular}{|c|c|c|}
\hline $\begin{array}{l}\text { Poverty } \\
\text { indicators }\end{array}$ & $\begin{array}{l}\text { Over the past year, how often, if ever, have you or anyone in your family } \\
\text { gone without: Enough food to eat? } \\
\text { Over the past year, how often, if ever, have you or anyone in your family } \\
\text { gone without: enough water? } \\
\text { Over the past year, how often, if ever, have you or anyone in your family } \\
\text { gone without: medical care? } \\
\text { Over the past year, how often, if ever, have you or anyone in your family } \\
\text { gone without cooking fuel? }\end{array}$ & $\begin{array}{l}\text { Never, Just } \\
\text { once or } \\
\text { twice, } \\
\text { Several } \\
\text { times, } \\
\text { Many } \\
\text { times, } \\
\text { Always }\end{array}$ \\
\hline $\begin{array}{l}\text { Sources } \\
\text { news }\end{array}$ & $\begin{array}{l}\text { How often do you get news from the following sources: Television? } \\
\text { How often do you get news from the following sources: Radio? } \\
\text { How often do you get news from the following sources: Newspapers? }\end{array}$ & $\begin{array}{l}\text { Never, Less } \\
\text { than once a } \\
\text { month, A } \\
\text { few times a } \\
\text { month, A } \\
\text { few times a } \\
\text { week, } \\
\text { Every day }\end{array}$ \\
\hline $\begin{array}{l}\text { Exposure to } \\
\text { outside world }\end{array}$ & $\begin{array}{l}\text { How often do you use a cell phone } \\
\text { How often do you use a computer } \\
\text { How often do you use the internet } \\
\text { How often do you travel } 10 \mathrm{~km} \text { or more from the place where you live now }\end{array}$ & $\begin{array}{l}\text { Never, Less } \\
\text { than once a } \\
\text { month, A } \\
\text { few times a } \\
\text { month, A } \\
\text { few times a } \\
\text { week, } \\
\text { Every day }\end{array}$ \\
\hline \multirow[t]{3}{*}{$\begin{array}{l}\text { Personal } \\
\text { characteristics }\end{array}$} & $\begin{array}{l}\text { Let's turn to your role in the community. Now I am going to read out a list } \\
\text { of groups that people join or attend. For each one, could you tell me whether } \\
\text { you are an official leader, an active member, an inactive member, or not a } \\
\text { member: A religious group } \\
\text { Let's turn to your role in the community. Now I am going to read out a list } \\
\text { of groups that people join or attend. For each one, could you tell me whether } \\
\text { you are an official leader, an active member, an inactive member, or not a } \\
\text { member: Some other voluntary association or community group? }\end{array}$ & $\begin{array}{l}\text { Not a } \\
\text { member, } \\
\text { Inactive } \\
\text { member, } \\
\text { Active } \\
\text { member, } \\
\text { Official } \\
\text { leader }\end{array}$ \\
\hline & How old are you & $18-110$ \\
\hline & How many languages do you speak well & $1-98$ \\
\hline $\begin{array}{l}\text { Trust in } \\
\text { informal } \\
\text { institutions }\end{array}$ & $\begin{array}{l}\text { How much do you trust each of the following, or haven't you heard enough } \\
\text { about them to say: Traditional leaders }\end{array}$ & $\begin{array}{l}\text { Not at all, } \\
\text { Just a little, } \\
\text { Somewhat, } \\
\text { A lot }\end{array}$ \\
\hline $\begin{array}{l}\text { Trust in } \\
\text { formal } \\
\text { institutions }\end{array}$ & $\begin{array}{l}\text { How much do you trust each of the following, or haven't you heard enough } \\
\text { about them to say: Parliament? } \\
\text { How much do you trust each of the following, or haven't you heard enough } \\
\text { about them to say: The Electoral Commission of [country] } \\
\text { How much do you trust each of the following, or haven't you heard enough } \\
\text { about them to say: Your Metropolitan, Municipal or District Assembly? } \\
\text { How much do you trust each of the following, or haven't you heard enough } \\
\text { about them to say: The Police? } \\
\text { How much do you trust each of the following, or haven't you heard enough } \\
\text { about them to say: Courts of law? }\end{array}$ & $\begin{array}{l}\text { Not at all, } \\
\text { Just a little, } \\
\text { Somewhat, } \\
\text { A lot }\end{array}$ \\
\hline $\begin{array}{l}\text { Quality of } \\
\text { formal } \\
\text { institutions }\end{array}$ & $\begin{array}{l}\text { How many of the following people do you think are involved in corruption, } \\
\text { or haven't you heard enough about them to say: Police? } \\
\text { How many of the following people do you think are involved in corruption, } \\
\text { or haven't you heard enough about them to say: Tax Officials } \\
\text { How many of the following people do you think are involved in corruption, } \\
\text { or haven't you heard enough about them to say: Judges and Magistrates? }\end{array}$ & $\begin{array}{l}\text { None, } \\
\text { Some of } \\
\text { them, Most } \\
\text { of them, All } \\
\text { of them }\end{array}$ \\
\hline
\end{tabular}




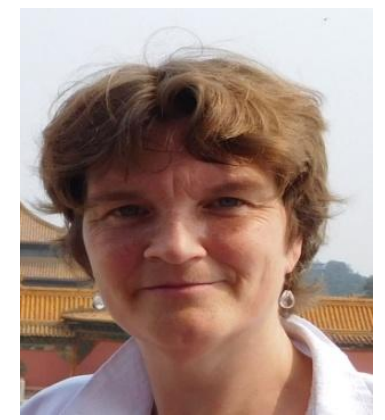

Lia van Wesenbeeck, is Director of the Amsterdam Centre for World Food Studies at VU University, Amsterdam and senior lecturer at Amsterdam University College. Her research interests include general equilibrium theory and applications, in particular focusing on the inclusion of biophysical characteristics and spatially explicit models of production, transport and natural flows. In addition, she has extensive experience in spatially explicit statistical analysis of survey and map data, and profiling of vulnerable groups. She has wide experience in international research consortia, and serves on various national and international boards and advisory committees.

Citation: C.F.A. van Wesenbeeck. "To Trust or Not to Trust? A Study of Trust and Economic Organization in West Africa "International Journal of Humanities Social Sciences and Education (IJHSSE), vol 7, no. 4, 2020 , pp. 52-69. doi: http://dx.doi.org/10.20431/2349-0381.0704007.

Copyright: (C) 2020 Authors. This is an open-access article distributed under the terms of the Creative Commons Attribution License, which permits unrestricted use, distribution, and reproduction in any medium, provided the original author and source are credited. 